Available online at http://journal.stkip-andi-matappa.ac.id/index.php/histogram/ Histogram : Jurnal Pendidikan Matematika ., 2019, 152 - 161

\title{
PELEVELAN LAPISAN PEMAHAMAN KONSEP MATEMATIKA SISWA KELAS X
}

\author{
Novisita Ratu \\ Universitas Kristen Satya Wacana \\ * Corresponding Author. Email: novisita.ratu@staff.uksw.edu \\ Received: 23 Juli 2019; Revised: 18 Agustus 2019 ; Accepted: 30 September 2019
}

\begin{abstract}
ABSTRAK
Penelitian ini bertujuan untuk menempatkan pemahaman konsep siswa kedalam level lapisan pemahaman konsep matematika. Lapisan pemahaman konsep pada penelitian ini berdasarkan pada teori Pirie\&Kieren yang terdiri dari primitive knowing, image making, image having, property noticing, formalizing, observing, structuring, inventising. Jenis penelitian adalah deskriptif kualitatif, dengan subjek penelitian siswa kelas X MIPA 7 SMAN 1 Salatiga. Hasil penelitian menunjukkan Sebesar 54,3\% siswa atau sebanyak 19 orang siswa berada pada level tertinggi yaitu inventising, sebesar 22,8\% siswa atau sebanyak 8 orang siswa pada level structuring, sebesar 2,9\% siswa atau sebanyak 1 orang siswa pada level Observing, sebesar 2,9 \% siswa pada level formalising, sebesar 14,2\% siswa atau sebanyak 5 orang siswa pada level primitive noticing, sebesar 2,9\% siswa atau sebanyak 1 orang siswa pada level image knowing/ having dan tidak terdapat siswa pada level primitive knowing dan image making. Berdasarkan hasil penelitian menunjukkan level lapisan pemahaman konsep setiap siswa berbeda-beda. Sehingga guru di dalam mengajarkan konsep matematika agar dapat memperhatikan keberagaman penguasaan konsep siswa.
\end{abstract}

Kata Kunci: Lapisan Pemahaman, Pirie\&Kieren, Matematika

How to Cite: Ratu, N. (2019). Pelevelan Lapisan Pemahaman Konsep Matematika Siswa Kelas X. Histogram: Jurnal Pendidikan Matematika, 3(2), 152 - 161, doi: http://dx.doi.org/10.31100/histogram.v3i2.404

Permalink/DOI: http://dx.doi.org/10.31100/histogram.v3i2.404

\section{PENDAHULUAN}

Matematika masih dianggap sulit oleh siswa, sulitnya matematika dipelajari oleh siswa dikarenakan sifat matematika yang abstrak. Hal ini sejalan dengan yang dikemukakan (Ruseffendi, 1988), bahwa masih banyak siswa-siswi menganggap This is open access article under the CC-BY-SA-license. 
matematika sebagai mata pelajaran yang sulit, sukar dan ruwet. Setelah belajar matematika masih banyak siswa belum mampu memahami konsep yang diajarkan bahkan pada konsep yang sangat sederhana sekalipun dipahami secara keliru. Kemampuan mengeneralisasi dan mengabstraksi konsep-konsep yang dipelajari siswa merupakan hal yang sangat penting dikuasai oleh siswa dalam memahami konsep-konsep matematika yang dipelajari, (Rohana, 2011).

Berpikir tingkat tinggi sangat dibutuhkan seseorang dalam memahami konsepkonsep matematika yang dipelajari. (Rosnawati, 2012), mengemukakan timbulnya berpikir tingkat tinggi dalam diri seseorang ketika orang tersebut mampu menghubungkan data sebelumnya yang telah dimiliki dengan informasi/data baru yang diperoleh, setelah itu disusun kembali, dikembangkan dan digunakan dalam memecahkan suatu masalah. Hal ini sejalan dengan (Cahyati \& Kriswandani, 2017), penguasaan suatu pengetahuan baru diperoleh dari kolaborasi antara pengetahuan yang sudah dimiliki sebelumnya dengan pengetahuan yang baru dimiliki. Oleh karena itu dalam pemahaman konsep dibutuhkan kemampuan berpikir tingkat tinggi.

Konsep-konsep dalam matematika saling berhubungan satu dengan yang lain. Penguasaan konsep dasar menjadi dasar untuk mempelajari konsep pada jenjang berikutnya, dimana konsep yang sederhana mendasari konsep yang lebih kompleks. Delapan Level Lapisan pemahaman konsep yang dimiliki siswa dikemukakan oleh Pirie\&Kieren. Delapan lapisan level lapisan pemahaman konsep tersebut adalah primitive knowing, image making, image having, property noticing, formalizing, observing, structuring, inventising (Piere, S.\&Kieren, 1994). Level lapisan pemahaman konsep digambarkan seperti bawang berlapis yaitu penguasaan konsep siswa semakin tinggi akan terlihat pada lapisan terluar dari bawang berlapis tersebut.

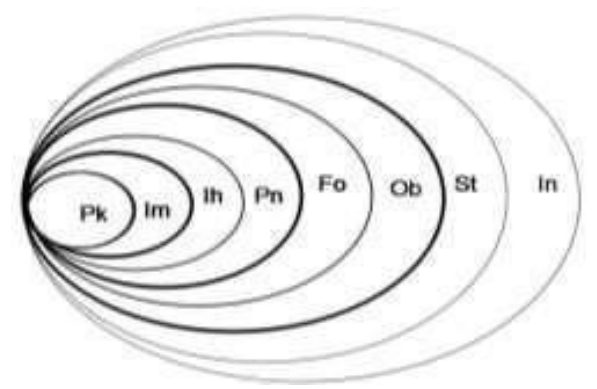

Gambar 1 Lapisan Pemahaman model Pirie \& Kieren 


\section{Histogram: Jurnal Pendidikan Matematika, 3 (2), 2019 - 154 Novisita Ratu}

Level lapisan pemahaman konsep primitive knowing merupakan kemampuan siswa untuk memahami definisi baru dengan menggunakan pengetahuan awal siswa ke level lapisan pemahaman berikutnya. Level lapisan pemahaman konsep image making merupakan kemampuan siswa dalam membangun pemahaman dan pengetahuan baru dari pengetahuan sebelumnya yang dimilki oleh siswa. Lapisan pemahaman konsep image having merupakan kemampuan siswa dalam membuat gambaran mental terkait suatu ide tertentu tanpa mengerjakan contoh-contoh terlebih dahulu. Lapisan pemahaman konsep propertynoticing merupakan kemampuan siswa mengkombinasikan aspek-aspek dari suatu ide untuk membangun sifat-sifat mendasar dari ide tersebut. Lapisan pemahaman konsep formalizing merupakan kemampuan siswa dalam mengabstraksi suatu konsep matematika dari sifat-sifat yang ditunjukan. Lapisan pemahaman observing merupakan kemampuan siswa menggunakan aktifitas formal pada level formalizing dalam pemecahan masalah terkait yang sedang dihadapinya. Lapisan pemahaman konsep structuring merupakan kemampuan siswa menghubungkan antara terorema dengan argument yang logis dan melakukan pembuktian teorema secara aksiomatik. Level lapisan pemahaman konsep inventising merupakan level tertinggi dimana siswa sudah memiliki pemahaman yang terstruktur serta memiliki kemampuan untuk menciptakan sebuah konsep baru dari pertanyaan-pertanyaan yang muncul.

Pemahaman konsep menjadi suatu hal yang sangat penting dalam mempelajari suatu materi. Matematika adalah salah satu materi yang wajib dikuasai oleh siswa, hal ini sesuai dengan kurikulum 2013 pada bagian kompetensi dasar (Safitri, Mulyani, \& Ratu, 2018). Menurut Permendikbud No.59 Tentang Kurikulum 2013, memahami konsep matematika terkait dengan kemampuan menjelaskan hubungan tiap konsep serta mengaplikasikanya, secara singkat, padat dan jelas serta tepat dalam pemecahan masalahnya. Apabila siswa mengalami kesulitan dalam memahami konsep matematika, maka siswa akan terhambat dalam penguasaan materi selanjutnya (Puspitasari \& Prihatnani, 2018).

Berdasarkan uraian di atas maka akan dilakukan penelitian terkait analisis level lapisan pemahaman konsep siswa kelas X MIPA 7, SMAN 1 Salatiga, tahun ajaran 2018/2019. Tujuan penelitian ini adalah menempatkan pemahaman konsep siswa kedalam level lapisan pemahaman konsep matematika. 


\section{METODE PENELITIAN}

Penelitian ini menggunakan lapisan pemahaman konsep yang diungkapkan oleh (Piere, S.\&Kieren, 1994) yang meliputi Primitive Knowing, Image Making, Image Having, Property Noticing, Formalising, Observing, Structuring, dan Inventising. Jenis penelitian adalah deskriptif kualitatif, bertujuan memberi gambaran level lapisan pemahaman konsep siswa terkait soal PISA. Subjek dalam penelitian ini sebanyak 35 siswa, kelas X MIPA 7, SMAN 1 Salatiga. Teknik pengambilan subjek adalah purposive sampling. Instrumen yang digunakan dalam penelitian adalah peneliti sendiri sebagai instrumen utama dan instrumen pendukung yaitu tiga soal PISA konten quantity. Teknik pengumpulan data terdiri dari tes dengan memberikan soal PISA dan wawancara dengan tujuan untuk melengkapi data yang dianggap kurang. Sesudah data dikumpulkan selanjutnya data dianalisis dengan memeriksa semua jawaban siswa dan dikelompokkan ke dalam lapisan pemahaman konsep siswa.

\section{HASIL DAN PEMBAHASAN}

Penelitian ini menggunakan lapisan pemahaman konsep yang diungkapkan oleh (Piere, S.\&Kieren, 1994) yang meliputi Primitive Knowing, Image Making, Image Having, Property Noticing, Formalising, Observing, Structuring, dan Inventising. Jenis penelitian adalah deskriptif kualitatif, bertujuan memberi gambaran level lapisan pemahaman konsep siswa terkait soal PISA. Subjek dalam penelitian ini sebanyak 35 siswa, kelas X MIPA 7, SMAN 1 Salatiga.

Soal PISA konten Quantity yang dipilih sebagai soal tes yaitu berapa banyak jumlah penguin di koloni pada akhir tahun. Hasil analsis jawaban subjek diperoleh bahwa level lapisan pemahaman konsep mengenai soal PISA konten Quantity pada setiap subjek berbeda-beda. Gambar 1 Hasil Analisis jawaban subjek dapat dilihat pada Tabel 1.

Tabel 1. Hasil Analisis Jawaban Subjek

\begin{tabular}{ccccccccc}
\hline & \multicolumn{8}{c}{ Level Lapisan Pemahaman Konsep } \\
\hline & PK & IM & IK & PN & FO & OB & ST & IN \\
\hline Jumlah Subjek & 0 & 0 & 1 & 5 & 1 & 1 & 8 & 19 \\
\hline Persentase & $0 \%$ & $0 \%$ & 2,9 & $14,2 \%$ & $2,9 \%$ & 2,9 & $22,8 \%$ & $54,3 \%$ \\
& & & $\%$ & & & $\%$ & &
\end{tabular}

(Sumber: Data Primer, Tahun: 2019) 
Keterangan :

$\begin{array}{ll}\mathrm{Pk}: \text { Primitive Knowing } & \mathrm{Im}: \text { Image Making } \\ \text { Ik : Image Knowing / Having } & \mathrm{Pn}: \text { Primitive Noticing } \\ \text { Fo : Formalising } & \mathrm{Ob}: \text { Observing } \\ \mathrm{St}: \text { Structuring } & \mathrm{In}: \text { Inventising }\end{array}$

Berdasarkan Tabel 1, Hasil analisis jawaban siswa Kelas X MIPA 7 menunjukkan 54,3\% atau sebanyak 19 siswa pada level lapisan pemahaman konsep Inventising, 22,8\% siswa atau sebanyak 8 siswa mencapai level lapisan pemahaman konsep sturcturing, sedangkan pada level lapisan pemahaman konsep Primitive Noticing terdapat 14,2\% siswa atau sebanyak 5 orang siswa, sedangkan pada level lapisan pemahaman konsep Observing, Formalising, dan Image Knowing/Having terdapat 2,9\% siswa atau sebanyak 1 orang siswa dan tidak ada siswa pada level lapisan pemahaman konsep Primitive Knowing dan Image making.

Level lapisan pemahaman konsep inventising merupakan level tertinggi dimana siswa sudah memiliki pemahaman yang terstruktur serta memiliki kemampuan untuk menciptakan sebuah konsep baru dari pertanyaan-pertanyaan yang muncul. Hasil pekerjaan salah satu subjek menunjukkan bahwa subjek mampu melakukan usaha awal dalam memahami soal tersebut dan dapat membawa pengetahuan sebelumnya ke lapisan pemahaman yang selanjutnya, yaitu subjek mengetahui informasi penting yang ada di soal, hal yang diketahui dari soal serta hal yang ditanyakan ditanyakan dalam soal. Selain itu subjek mampu memberi gambaran seluruh tahap-tahap umum seluruh soal yaitu dengan merencanakan langkah penyelesaian dalam soal, serta dapat membuat abstraksi penyelesaian soal terperinci tanpa menggunakan contoh-contoh yaitu dengan menjelaskan dan menuliskan langkah-langkah penyelesaian. Berdasarkan hasil pekerjaan, subjek mampu menuliskan hal-hal diketahui dan yang ditanyakan dalam soal. Sehingga subjek telah melewati lapisan primitive knowing, image making, dan image having.

Subjek juga dapat mengaitkan gambaran abstrak dengan konsep yaitu menjumlahkan banyaknya penguin awal dengan anak penguin, hasil tersebut dikalikan $20 \%$ sehingga diperoleh penguin yang mati, kemudian dari total penguin awal dengan anak penguin dikurangi dengan penguin yang mati. Oleh karena itu, subjek telah melewati lapisan property noticing. Subjek juga dapat menerapkan aturan-aturan yang sudah diketahui pada level sebelumnya dengan benar, yaitu dengan mensubtitusikan jumlah 


\section{Histogram: Jurnal Pendidikan Matematika, 3 (2), 2019 - 157 Novisita Ratu}

penguin awal sebanyak 10.000 dan anak penguin sebanyak 5.000 sehingga hasilnya adalah 15.000, banyaknya penguin yang mati yaitu $20 \%$ dari 15.000 diperoleh 3.000 , kemudian 15.000 dikurangi 3.000 diperoleh 12.000. sehingga S8 dapat mencapai lapisan pemahaman konsep yaitu formalising.

Subjek melakukan pengecekan kembali tahapan-tahapan penyelesaian yang sudah dikerjakan, serta subjek dapat menyusun penyelesaian soal secara terstruktur dan lengkap sehingga memperoleh hasil akhir yaitu 12.000 penguin yang hidup. Hal ini terlihat bahwa subjek dapat menyelesaikan jawaban secara tepat, sehingga subjek dapat melewati lapisan observing dan structuring.

Selanjunya subjek dapat membuat dan memeberikan pertanyaan-pertanyaan baru dan dapat membangun suatu konsep baru berdasarkan pemahaman terstruktur dari soalsoal yang berhasil diselesaikan dengan benar, dimana subjek dapat menyimpulkan bahwa jumlah penguin di koloni tersebut adalah 12.000, sehingga S8 mencapai lapisan ke 8 yaitu inventising. Berikut contoh pekerjaan salah satu subjek.

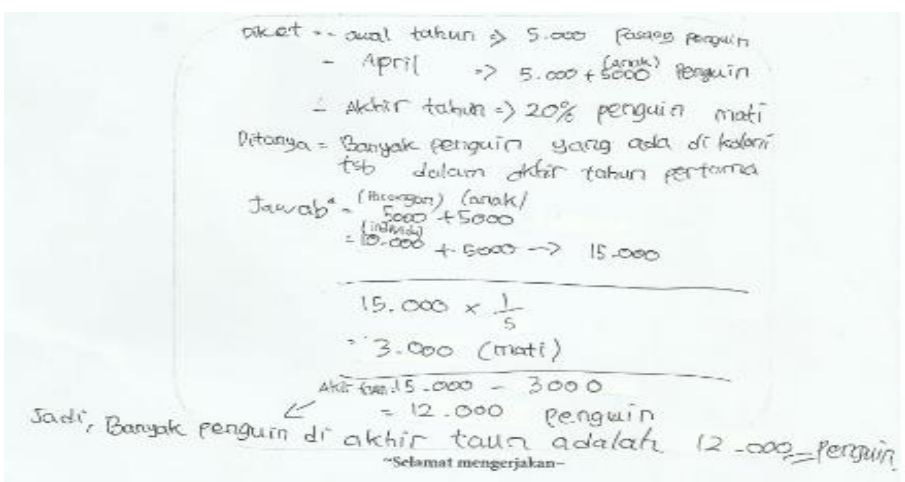

Gambar 1. Contoh hasil pekerjaan pada level lapisan pemahaman inventising

Pada level Lapisan pemahaman konsep structuring subjek dapat menghubungkan antara terorema dengan argument yang logis dan melakukan pembuktian teorema secara aksiomatik. Hasil pekerjaan salah satu subjek menunjukkan bahwa subjek mampu melakukan usaha awal dalam memahami soal tersebut dan dapat membawa pengetahuan sebelumnya ke lapisan pemahaman yang selanjutnya yaitu mengetahui informasi penting dalam soal, hal-hal yang diketahui ataupun ditanyakan dari soal. Selain itu subjek dapat memberi gambaran seluruh tahap-tahap umum dalam menyelesaikan soal yaitu dengan merencanakan langkah penyelesaian dalam soal, serta subjek dapat mengabstraksikan 
penyelesaian soal secara rinci tanpa memberikan contoh-contoh yaitu dengan menjelaskan dan menuliskan langkah-langkah penyelesaian. Berdasarkan hasil pekerjaan subjek menunjukkan bahwa subjek dapat menuliskan apa yang diketahui dan apa yang ditanya dalam soal. Sehingga Subjek telah melewati lapisan primitive knowing, image making, dan image having.

Subjek juga dapat mengaitkan gambaran abstrak dengan konsep yang ada yaitu menjumlahkan banyaknya penguin awal dengan anak penguin, hasil tersebut dikalikan $20 \%$ sehingga diperoleh penguin yang mati, kemudian dari total penguin awal dengan anak penguin dikurangi dengan penguin yang mati. Oleh karena itu, subjek telah melewati lapisan property noticing. Subjek juga dapat menerapkan aturan-aturan yang telah diketahui pada level sebelumnya dengan tepat, yaitu dengan mensubtitusikan jumlah penguin awal sebanyak 10.000 dan anak penguin sebanyak 5.000 sehingga hasilnya adalah 15.000, banyaknya penguin yang mati yaitu $20 \%$ dari 15.000 diperoleh 3.000 , kemudian 15.000 dikurangi 3.000 diperoleh 12.000. sehingga subjek dapat mencapai lapisan pemahaman konsep yaitu formalising.

Subjek dapat melakukan pengecekan kembali tahapan-tahapan dalam penyelesaian soal, serta subjek dapat menyusun penyelesaian soal secara terstruktur dan lengkap sehingga memperoleh hasil akhir yaitu 12.000 penguin yang hidup, namun pada akhir jawaban subjek tidak dapat menyimpulkan apa yang telah ditemukan. Hal ini terlihat bahwa subjek dapat menyelesaikan jawaban secara tepat, sehingga subjek dapat melewati lapisan observing dan structuring namun belum mencapai level Inventising, karena belum dapat menciptakan suatu konsep yang baru.

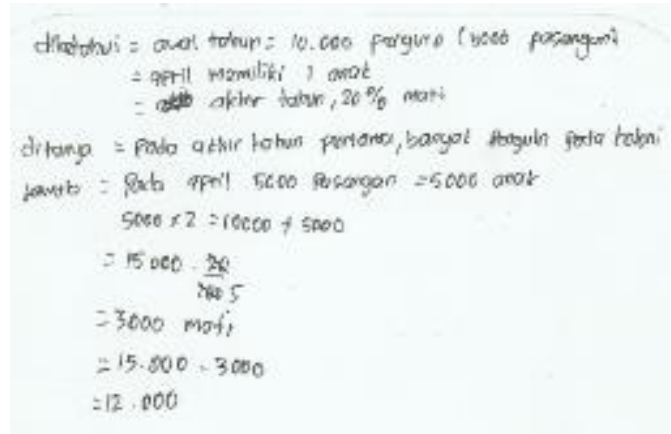

Gambar 2. Contoh hasil pekerjaan pada level lapisan pemahaman structuring

Pada level pemahaman konsep Primitive Noticing berdasarkan pekerjaan salah seorang subjek menunjukkan bahwa subjek mampu melakukan usaha awal dalam 
memahami soal tersebut dan dapat membawa pengetahuan sebelumnya ke lapisan pemahaman yang selanjutnya yaitu mengetahui apa yang diketahui dan ditanyakan dalam soal. Selain itu subjek dapat membuat gambaran seluruh tahap-tahap umum seluruh soal yaitu dengan merencanakan langkah penyelesaian dalam soal, serta subjek dapat membuat abstraksi penyelesaian soal terperinci tanpa menggunakan contoh-contoh yaitu dengan menjelaskan dan menuliskan langkah-langkah penyelesaian. Sehingga subjek telah melewati lapisan primitive knowing, image making, dan image having.

Subjek juga dapat menghubungkan gambaran abstrak yang dimiliki dengan konsep yaitu menjumlahkan banyaknya penguin awal dengan anak penguin, hasil tersebut dikalikan 20\% sehingga diperoleh penguin yang mati, kemudian dari total penguin awal dengan anak penguin dikurangi dengan penguin yang mati. Oleh karena itu, subjek telah melewati lapisan property noticing. Subjek juga dapat mengaplikasikan sifat-sifat yang telah diketahui pada level sebelumnya dengan tepat, yaitu dengan mensubtitusikan jumlah penguin awal sebanyak 10.000 dan anak penguin sebanyak 5.000 sehingga hasilnya adalah 15.000, banyaknya penguin yang mati yaitu $20 \%$ dari 15.000 diperoleh 3.000 , namun subjek tidak melanjutkan penyelesaian dengan mengurangi 15.000 dengan 3.000, sehingga subjek tidak dapat mencapai lapisan pemahaman konsep yaitu formalising dan hanya sampai pada lapisan property noticing.

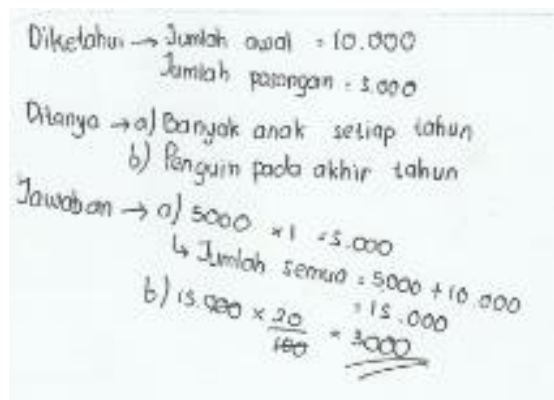

Gambar 3. Contoh hasil pekerjaan pada level lapisan pemahaman primitive noticing

Pada level lapisan pemahaman konsep Image Knowing, berdasarkan pekerjaan salah satu subjek menunjukkan bahwa subjek mampu melakukan usaha awal dalam memahami soal tersebut dan dapat membawa pengetahuan sebelumnya ke lapisan pemahaman yang selanjutnya yaitu mengetahui apa yang diketahui dan ditanyakan dalam 
soal. Selain itu subjek dapat membuat gambaran seluruh tahap-tahap umum seluruh soal yaitu dengan merencanakan langkah penyelesaian dalam soal, serta subjek dapat membuat abstraksi penyelesaian soal terperinci tanpa menggunakan contoh-contoh yaitu dengan menjelaskan dan menuliskan langkah-langkah penyelesaian. Berdasarkan hasil pekerjaan subjek menunjukkan bahwa subjek dapat menuliskan apa yang diketahui dan apa yang ditanya dalam soal. Sehingga subjek telah melewati lapisan primitive knowing, image making, dan image having.

Namun subjek tidak dapat menghubungkan gambaran abstrak yang dimiliki dengan konsep yaitu menjumlahkan banyaknya penguin awal dengan anak penguin, hasil tersebut dikalikan $20 \%$ sehingga diperoleh penguin yang mati, kemudian dari total penguin awal dengan anak penguin dikurangi dengan penguin yang mati. Oleh karena itu, subjek tidak dapat melewati lapisan property noticing dan hanya sampai pada lapisan image knowing.

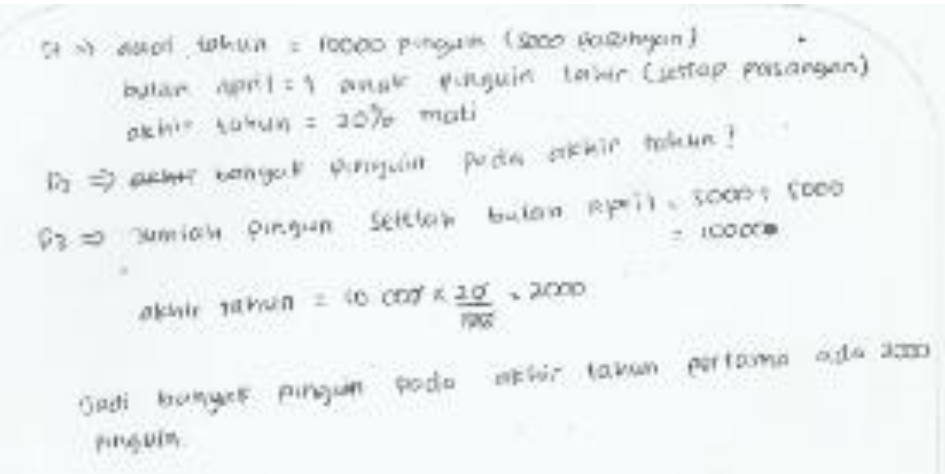

Gambar 4. Contoh hasil pekerjaan pada level lapisan pemahaman image knowing

\section{KESIMPULAN DAN SARAN}

\section{A. Kesimpulan}

Analisis level lapisan pemahaman konsep pada siswa kelas X MIPA 7 SMAN 1 Salatiga memiliki level yang beragam. Sebesar $54,3 \%$ siswa atau sebanyak 19 orang siswa berada pada level tertinggi yaitu inventising sebesar $22,8 \%$ siswa atau sebanyak 8 orang siswa pada level structuring, sebesar 2,9\% siswa atau sebanyak 1 orang siswa pada level Observing, sebesar 2,9\% siswa pada level formalising, sebesar 14,2\% siswa atau sebanyak 5 orang siswa pada level primitive noticing, sebesar $2,9 \%$ siswa atau sebanyak 1 orang 


\section{Histogram: Jurnal Pendidikan Matematika, 3 (2), 2019 - 161 \\ Novisita Ratu}

siswa pada level image knowing/ having dan tidak terdapat siswa pada level primitive knowing dan image making.

\section{B. Saran}

Beragamnya Level lapisan pemahaman konsep siswa memberi gambaran bagi para pendidik dalam merancang suatu pembelajaran matematika yang berpusat pada penanaman konsep, sehingga saran dari penelitian ini adalah penguasaan konsep dasar siswa menjadi dasar bagi siswa untuk mempelajari konsep-konsep selanjutnya. Guru perlu memperhatikan level pemahaman konsep siswa dan memperkuat konsep-konsep dasar yang harus dikuasai siswa untuk mempelajari konsep selanjutnya.

\section{DAFTAR PUSTAKA}

Cahyati, A. M. D., \& Kriswandani, K. (2017). Lapisan Pemahaman Konsep Matematika Dalam Menyelesaikan Soal TIMSS Bagi Siswa SMP Kelas VIII. Jurnal Inovasi Pendidikan Dan Pembelajaran Matematika, 3(2), 83-97.

Piere, S.\&Kieren, T. (1994). Growth in Mathematical Understanding: How we Can Characterize it an How can Represent it. Education Studies in Mathematics, 9, 160190.

Puspitasari, A. P., \& Prihatnani, E. (2018). Deskripsi Pemahaman Konsep Kejadian Majemuk Siswa Kelas XI IPA SMA Negeri 3 Salatiga. Mitra Pendidikan, 2(1), 117133.

Rohana. (2011). Pengaruh Pembelajaran Berbasis Masalah terhadap Pemahaman Konsep Mahasiswa Prodi Pendidikan Matematika FKIP UNIVERSITAS PGRI PALEMBANG. Prosiding Seminar Nasional Pendidikan "Pendidikan Di Era Globalisasi Dalam Menghadapi Tantangan Masa Depan”. Universitas PGRI Palembang. ISBN 978-602-95793-1-4.

Rosnawati, R. (2012). Enam Tahapan Aktivitas Dalam Pembelajaran Matematika Untuk Medayagunakan Berpikir Tingkat Tinggi Siswa. 1-12.

Ruseffendi. (1988). Pengantar Kepada Membantu Guru Mengembangkan Kompetensinya dalam Pengajaran Matematika untuk Meningkatkan CBSA: Perkembangan Kompetensi Guru.

Safitri, R. I., Mulyani, S., \& Ratu, N. (2018). Profil Lapisan Pemahaman Konsep Siswa SMP Terkait Garis Tinggi Segitiga. Jurnal Ilmiah Soulmath: Jurnal Edukasi Pendidikan Matematika, 6(2), 65. https://doi.org/10.25139/smj.v6i2.1141 